\author{
Д.В. Сичинава \\ Институт русского языка им. В.В. Виноградова РАН / \\ НИУ «Высшая школа экономики» \\ (Москва, Россия) \\ mitrius@gmail.com
}

\title{
К ИНТЕРПРЕТАЦИИ НЕКОТОРЫХ БЕРЕСТЯНЫХ ГРАМОТ
}

В данной статье я излагаю наблюдения, связанные с интерпретацией четырёх берестяных грамот. Эти наблюдения накопились при подготовке посмертного издания книги А. А. Зализняка «Древненовгородский диалект. Дополнение», над которой он (параллельно с новой редакцией «Древнерусского ударения») работал до последних дней жизни. В настоящее время эта книга готовится к публикации под редакцией А.А. Гиппиуса, моей и М.Н. Толстой.

Статья распадается на две части, посвященные двум грамотам каждая: это коррективы к чтению давно найденных берестяных грамот, связанные с фонетическими явлениями, которые были выявлены уже после новых находок, и интерпретации надписей на берестяных рисунках. Коррективы, предложенные в первой части, кажутся наиболее надёжными. Что касается надписей на рисунках, то здесь речь идёт лишь о версиях: скудный контекст и высоковероятное наличие искажений не дают возможности настаивать на предложенных решениях с полной уверенностью. Соответственно, наиболее развёрнуто изложены именно эти, менее надёжные гипотезы, с учётом «за» и «против».

Поправки и дополнения к чтениям берестяных грамот (в том числе к найденным когда-то им самим) всегда приносили А. А. Зализняку большую радость. Особенно ему нравилось, когда открытия новых текстов помогали пересмотреть давно устоявшиеся чтения «старых» грамот: «эта версия продержалась тридцать лет, пока не пала...». Для таких сюжетов он не жалел времени на своих публичных «берестяных» лекциях, приравнивая их к новым находкам документов. Думаю, подобная статья (раздел 1.1. которой подхватывает тему последней статьи Андрея Анатольевича) будет уместна в сборнике его памяти.

Ключевые слова: берестяные грамоты, древненовгородский диалект, фонетические изменения, орфография, колбяги, рисунки, гимнография.

* Работа выполнена в Институте славяноведения РАН за счет гранта Российского научного фонда (проект № 19-18-00352). 


\section{1. «Новые» фонетические явления и темные места в «старых» грамотах}

\section{1. Грамота 831: Лукерья и колбяги}

Грамота № 831 (вторая четверть XII в.) — это один из самых длинных берестяных текстов: письмо от Кузьмы «и его детей» к старейшине Рагуилу, которого автор упрекает в необоснованных, в том числе судебных, претензиях, несмотря на лояльное поведение самого Кузьмы. Это также единственный заведомо известный нам черновик будущего послания на пергамене, что видно из финальной инструкции автора писцу Степану. Нас интересует следующий весьма эмоциональный пассаж:

... боудьть да то тоу боудоу ото нхо посадь[ник]о(у) [c]о [пи](скоупомо...) ото весьхо шьсть. А ни ^ тобе кобАжанино, ни ^ то[бь] скоу[дь]тина! А и горъзно ми [бе]шь тоу(жьно) тьгда.

В «Древненовгородском диалекте» [Зализняк 2004: 303] эта часть толкуется так (с учетом конъектур, предложенных в [Гиппиус 2004б: 224-226]):

«...дескать, я тут от них от всех (т. е. от своих детей) посаднику с [епископом заплатил только] шесть (вероятно, гривен). А я тебе не кобяжанин, я тебе не «скудятина» (т. е. нищий)! А уж очень мне было туго (?) тогда».

Итак, Рагуил несправедливо обвиняет семью Кузьмы («я и мои дети» постоянно выступают в грамоте как единый субъект) в недостаточной уплате податей. В издании [Янин, Зализняк, Гиппиус 2004: 50] это место откомментировано подробнее: «Для боудоу (заплатиль) при такой интерпретации предполагается модальное значение, приблизительно переданное с помощью 'дескать'». Предыдущее слово боудыть - по гипотезе А.А. Гиппиуса [20046: 226], финал фразы типа 'Если кто-то тебе про меня и про моих детей сказал...’; «при этом глагол, как и в следующей фразе, раскрывающей содержание этого гипотетического высказывания, стоял в предположительном наклонении (например, рекль будеть)». Семантика двух форм второго будущего (А.А. Зализняк и вслед за ним А. А. Гиппиус используют термин «предположительное наклонение») — как в боудоу (заплатиль) со значением 'якобы, дескать', так и в (рекль) боудьть со значением условия - прекрасно соответствует типологически выявленным Я.А. Пеньковой для предбудущего значениям (ср. [Пенькова 2018] и ряд других её работ). Однако в специальной статье Я. А. Пеньковой [2019] о втором будущем в берестяных грамотах эти реконструируемые два вхождения не учтены (как и некоторые другие не столь надёжные примеры, тоже основанные на тех или иных конъектурах: №430, 592 [Гиппиус, Зализняк 2015: 240, 251-252], № 834 [Зализняк 2004: 311-312]). Ближе всего к семантике снятой утвердительности ('якобы, дескать') пример из берестяной грамоты № 531: оже боудоу люди при комо боудоу дала роукоу за зАте 'если будут свидетели, при ком я [якобы] поручилась за зятя’ ([Пенькова 2019: 74]; там же параллели из книжных памятников).

В ответ Кузьма заверяет в своей платежеспособности, ссылается на трудные обстоятельства и восклицает, что он не «кобяжанин» и не «скудятина» (не 
исключено, что в грамоте прямо так и написано скоу[дА]тина, но возможно и скоу $[\partial b]$ тина с ранним переходом [а] в [е] между мягкими). Ни то, ни другое слово ранее в источниках не встречалось. А.А. Зализняк комментирует это место так: «Остается пока невыясненным, кто были те презренные кобяжане, приравнивание к которым Кузьма считает для себя оскорблением. Здесь слово кобяжанинъ, повидимому, выступает как синоним скряги, скупца. Бранное слово скудятина образовано по той же модели, что современные разговорные и диалектные дохля́тина, мерзля́тина, серя́тина, подля́тина, грубя́тина и др. (все они могут относиться и к человеку)» [Зализняк 2004: 303-304]. А. А. Гиппиус объясняет эти слова схожим образом: «Можно понять и смысл упоминания в этом контексте загадочного кобяжанина. Это слово, по-видимому, выступает здесь как экспрессивное обозначение скупца, синоним скряги, скупердяя. Таким же экспрессивным синонимом для бедняка, нищего является «скудятина»» [Гиппиус 2004б: 226].

В словоуказателе к «Древненовгородскому диалекту» [Зализняк 2004: 748] слово кобАжанинъ получило пометку жит.; иными словами, суффикс -јан- интерпретируется как образующий имя жителя некого населенного пункта или территории, аналогично хорошо известным названиям кылғнинъ (от Кьлєвъ), бужанинъ (от Бугъ), рушанинъ (от Руса), имоволожанинъ (от Имоволожь или Имоволоже), волочанинъ (от Волокъ), шижнднинъ (от Шижна) и т. д. (ср. список встретившихся до 2004 г. на бересте таких катойконимов в обратном индексе к словоуказателю [Там же: 833]). Однако как называлась территория, жители которой получили столь красноречивую репутацию (теоретических вариантов топонима тут с учетом чередований последнего согласного основы, морфологического рода и возможных суффиксов, немало: *Коблжьско, *Коблдинъ, *Коблга и многое другое), было неясно, и какую-либо этимологию для этой основы предложить было затруднительно.

Кажется, сейчас уже можно ответить на вопрос о том, «кто были те презренные кобяжане», с большей определенностью.

Последняя статья А. А. Зализняка «Эффект Лукерьи» [Зализняк 2019] посвящена последней грамоте, найденной при его жизни — грамоте № 1102, где речь идет о подготовке поминок. В ней рассматривается ранее не описанный фонетический эффект ол > o, названный в честь автора грамоты № 1102 (середина XIV в.) - новгородки Лукерьи, которая «на бегу» (илю ти биж А) чрезвычайно точно фонетически записывала свою речь, в частности, дважды написала потину, потиноу вместо полтину. Обнаружились как более ранние примеры такого перехода в берестяных грамотах (по изетверта 'три с половиной' в № 707, посл. треть XIII в., потори коробии 'полторы коробьи’ в №689, 60-70-х гг. XIV в., поторь коробьи в №521, посл. четв. XIV - нач. XV в.), так и многочисленные систематически не исследованные параллели в современных говорах, замечательные примеры современных фамилий типа Поторацкий, Хостинкин или Токачев, а также вошедшая в литературные восточнославянские языки утрата [л] в слове солнще. При подготовке книги «Древненовгородский диалект. Дополнение» А. А. Гиппиус поставил в этот же ряд 
и исправление з догомъ на з долгомъ (л вписано над строкой) в грамоте Ст. Р. 39 (последняя четверть XIV в.).

Учёт перехода ол > о позволяет видеть в слове кобяжанинъ этнонимическую основу кълбжг-. Это обозначение северного народа, дважды упоминаемого в Русской Правде (оба раза рядом с варягами), а также в ряде других источников, в том числе скандинавских и греческих. Этимологически его связывают с др.-сканд. kylfingr от kylfa 'дубина'; название колбягов, не содержащее прогрессивной палатализации, «входит в ряд заимствований из древнескандинавского, воспринятых несомненно в первую очередь новгородско-псковским диалектом» [Зализняк 2004: 46]. Ряд исследователей [Рыдзевская 1934: 511; Мачинский, Мачинская 1988; Кулешов, Мачинский 2004] видит в колбягах приладожских финнов, испытавших скандинавское влияние, археологическим свидетельством деятельности которых является приладожская курганная культура. Существует также ряд других толкований этого этно(социо)нима; ср. недавний обзор с общим скептическим выводом насчёт самой возможности археологической локализации колбягов [Михайлова 2019]. В берестяных грамотах колбяги упоминаются только один раз, в документе № 222 (первое двадцатилетие XIII в.), в не совсем ясном контексте: запутанные финансовые дела двух княжеских сборщиков подати зависят, в частности, от того, «бежали» колбяги или нет.

После этого шага можно попробовать найти и исходный топоним, ставший основой для нарицательного употребления в грамоте № 831. КълбАжанинъ - это житель населенного пункта, название которого содержит основу кълбяг-, например, деревни Ко́лбяги (в более позднем виде Ко́лбеги (-га) и ныне Ко́лбеки в Бокситогорском районе Ленинградской области). Возможны и иные кандидаты: так, с 1501 г. известен также погост Колбежицы, административный центр Колбежицкой губы, в современном Островском районе Псковской области. Ср. аналогичный ряд от тесно связанного с этим этнонимом в Русской Правде названия вардгъ: Ве́ряжа (река) и другие подобные названия, от варианта *върдгъ, более точно отражающем *vaering- [Васильев 2012: 343-347] - вережане (в маргиналии, интерполированной в текст «Устава Ярослава о мостех», см. [Гиппиус 2005]). Не исключено, что кълбАжанинъ могло быть и просто более редким обозначением колбяга (ср. сингулятив вожанинъ от водь), «что, впрочем, может сводиться к одному и тому же», как сказал бы А. А. Зализняк [2004: 241, 289, 384], ведь Колбяги явно получили название по жителям, а соответствующий этнос в XII веке заведомо существовал.

Не удивительно, что носителей приладожской курганной культуры, «живших в маленьких неукреплённых посёлках, вдалеке от военно-торговых центров типа Ладоги, Смоленска/Гнёздова или Киева» [Кулешов, Мачинский 2004: 210-211], в столице Новгородской земли могли считать неплатежеспособными - будь то по бедности или по скупости. Более того, как сообщил нам Вяч. С. Кулешов (по неизданным этнографическим данным С. Л. Кузьмина), слово колбя́жка в юго-восточном Приладожье дожило даже до ХХ в. и считалось у старожилов уничижительным/оскорбительным ещё в 1980-1990-е годы. Но и это ещё не всё. Адресат 
письма, состоятельный боярин «Рагуил старший», по гипотезе А.А. Гиппиуса [Гиппиус 2004a: 181], тождествен Рагуилу, получившему в 1132 году посадничество в Ладоге. Как бы «вдалеке» от города Ладоги ни находились посёлки колбягов/ колбяжан (до собственно Колбягов/Колбеков от нее 150 км; впрочем, многие археологические следы соответствующей культуры, например, на реке Сясь, заметно ближе), эти люди заведомо были знакомы ладожскому посаднику, который мог первым обозвать Кузьму «колбяжанином и скудятиной», а тот в таком случае возмущенно это опровергает, цитируя характерные словечки обидчика. Если этот Рагуил ещё и действительно принадлежал к потомкам Рёгнвальда Ульвссона, получившего Ладогу в ярлство еще в начале XI в. (гипотеза о родстве с ним нескольких семейств новгородского боярства принадлежит А.А. Молчанову и развита, опять же, Гиппиусом [2006: 103]), то, конечно, он мог относиться к скандинавизированному финскому населению этих краёв свысока.

Учитывая наличие четырёх или пяти описок [Зализняк 2004: 304] в этой длинной грамоте, надо проверить и версию о простом пропуске л в ко(л)бАжанино. Однако типологически эти описки объясняются легко (повтор, предвосхищение, смешение похожих букв), в то время как пропуск л графическим контекстом не мотивирован.

Такое прочтение не только убедительно объясняет тёмное место грамоты и пополняет немногочисленный фонд свидетельств источников о колбягах, но и имеет важные лингвистические последствия. Во-первых, «эффект Лукерьи», первые примеры которого датировались XIII в., удревняется до второй четверти XII в.

Во-вторых, сразу же встаёт вопрос об относительной хронологии этого изменения; как отмечает А.А. Зализняк [2019], «с хронологической точки зрения начало перехода [ол] в закрытом слоге в [о] должно быть отнесено ко времени... не ранее прояснения (а тем самым и падения) редуцированных (поскольку вл должно было успеть перейти в ол)». С учётом того, что в этой грамоте уже есть один пример позднедревнерусского состояния (полоуторь, здесь -b $=<-b>$ ), надо полагать, что и в основе кълблг- редуцированный перед плавным еще до осуществления данного эффекта прояснился ${ }^{1}$. Таким образом, грамота № 831 становится важным документом по истории эволюции редуцированных. Только дополнительные фонетические изменения в основах коблг- < кълбяг- и полоутор- < поль+втор- вынудили Кузьму «выдать» результаты падения и прояснения редуцированных на письме (в то время как в остальном безупречное раннедревнерусское состояние его большого послания может быть отчасти результатом отличного применения орфографических правил).

${ }^{1}$ Имеется также этимология [Кулешов, Мачинский 2004], согласно которой слав. колб Агъ (не кълблгъ!) < герм. *kalb-ing от *kalba- 'меч', сохранённого в финском kalpa 'вид меча' (ср. ответ одного из соавторов на возникшую полемику: [Кулешов 2014]), отделяемое от означающего тот же этнос скандинавского kylfingr от kylfa 'дубина'. Ожидалось бы, правда, *колобдгъ (стандартный восточнославянский рефлекс) или по крайней мере северные варианты типа *колыблгъ или *клобягъ (об этих рефлексах см. [Зализняк 2004: 39-40]). Вопреки соавторам, колобдгь в берестяной грамоте № 222 нельзя считать свидетельством полногласного рефлекса; при традиционной этимологии эта запись без труда объясняется как обычный новгородский диалектный рефлекс $T ъ r ъ T$, развившийся из * $T$ ъ $r T$ [там же: 43-44] и записанный по бытовой орфографии. 


\section{2. Грамота 528: «Вологодский» Гяков в столице}

Только что разобранная грамота Кузьмы (№ 831) - длинный риторически выстроенный и аргументированный текст, достойный пергамена, на который Степан его перепишет. Грамота Лукерьи (№ 1102) поначалу казалась малограмотной, но позже оказалась фонетически адекватной и с уместными синтаксическими эллипсисами. А письмо отца к Александру (№ 538, 70-80-е годы XIV века) - редкое в корпусе берестяной письменности действительно неумелое и небрежное (на разных языковых уровнях) сочинение. Приводим его текст с комментарием А. А. Зализняка; финал (после Климу) даём без разделения на слова.

От[о]ци поклонь к Олоскадру. [Сто б]ы [еси] д[об](рь дос)пъле сто у тьбь сиры, то бы еси ма[сло], то бы еси продАле с Климомь. А А тобъ клАнаосА: продАва да бы еси Климу. гиевькАстопанАбратомьгАковА

«Письмо начинается несколько нестандартной адресной формулой: 'Отчий поклон к Олеска(н)дру'. Основная фраза текста, возможно, означает: 'Управился бы ты хорошенько с теми, что у тебя, сырами; а масло бы продал с помощью Клима (или: [отправив] с Климом)'. Или, несколько иначе: 'Если ты [уже] хорошо управился с теми, что у тебя, сырами, то продал бы ты [и] масло с помощью Клима'. Далее: 'А я тебе кланяюсь: продавал бы ты Климу'. По-видимому, это просто повторение предыдущего совета (Клим мог выступать в роли перекупщика). После этого идет некий реестр, о характере связи которого с основным содержанием письма можно лишь строить предположения: '3 - Иевко, Степан с братом, 3 - Яков' (мы принимаем здесь предложенную В.Б. Крысько [1993: 83] трактовку словоформ ИевькА, СтопанА, АковА как номинативов; в издании и в НГБ VIII они рассматривались как генитивы)» [Зализняк 2004: 577].

Начиная с издания, две буквы 2 в заключительной фразе грамоты (гиевькА, гАковА) интерпретировались как цифры перед именами: ' 3 - Иевко, <...> 3 Яков’, хотя титла или точек при них нет и аналогичное положение цифр в реестрах на бересте не известно.

После находки в 2015 г. примера ГАково в вологодской грамоте №1 (XIV в.) [Кукушкин, Гиппиус, Зализняк 2018], где через гА передано [ја], в грамоте №528 следует видеть два примера такой же редкой записи начальной йотации, причем один раз просто с тем же самым именем. Запись йота через г была известна на бересте и ранее (погиха(ти) 'поехать' в №266, мравгици 'муравьичей' в №273), однако увидеть ее в начале слова, где часто можно предположить цифру, и тем более в начале имени собственного психологически сложнее.

Для ГиевькА тем самым надо предполагать произношение с начальным [jи], ср. иную фонетику после предлога: оүв ЫІєвка в грамоте № $521^{2}$.

2 [Примечание А.А. Гиппиуса.] Яркое наблюдение Д. В. Сичинавы, превращающее непонятные 3 ИевкА и 3 АковА в фонетически закономерные ГиевкА и ГАковА, само по себе не проясняет смысла последней фразы и ее связи с остальным текстом, а грамота в целом продолжает 


\section{2. Две подписи под картинками}

\subsection{K вопросу о дате на бересте}

Большую литературу вызвала дата, усматриваемая исследователями на двусторонней берестяной иконке с изображением Христа и св. мученицы Варвары начала XI в. (№ 915-И): достаточно сказать, что вокруг нее велась в свое время дискуссия с участием А. Т. Фоменко и Г. В. Носовского (подробности выступления которых мы опустим).

Краткое резюме возможных интерпретаций даты под образком св. Варвары, принятое в [Зализняк 2004: 276], выглядит так: «Внизу: ᄅ[??];; после е стоит либо неумело написанное $\phi$, либо латинское D; на третьем месте стоит либо о, либо $\boldsymbol{\Lambda}$ (различить их затруднительно). Это явно запись даты, но, по-видимому, неумелая. Интерпретация ефоз (или еD०з) дает дату 6577, т. е. 1069 г.; интерпретация 2фкз, (которая лучше соответствует стратиграфической дате) дает 6537, т. е. 1029 г.».

производить впечатление написанной крайне неумело. И все же это наблюдение позволяет, как кажется, приблизиться к пониманию того, что хотел сказать автор письма, а также причин постигшей его неудачи. Реконструируя замысел грамоты, естественно думать, во-первых, что перечень ГиевькА, Стопанд $<c>$ братомь, ГАковА должен был каким-то образом вписаться в смысловую и синтаксическую структуру текста. Единственным способом включить его в эту структуру выглядит связь со словами с Климом в составе фразы примерно следующего вида: 'С Климом (заодно действуют/торгуют) Иевко, Степан с братом, Яков'. Таким образом устраняется и видимое противоречие между указаниями продать Климу и продать «с Климом». Далее, для слов сто у тьбь сиры, которые А.А. Зализняк трактует как дополнение при досnъле, более подходящим кажется положение в начале синтаксического периода, ср. начало № 713 : Цето ти воудоро, цето ти церъмени, цето ти роудавещене и голоубине добре... '[Всё], сколько у тебя есть выдр, сколько у тебя есть красной ткани, сколько у тебя есть хорошей буро-красной и голубой ткани ...» (следовало указание, что со всем этим товаром нужно сделать)' [Зализняк 2004: 426]. Фраза Сто бы еси добрв доспьле оказывается в таком случае синтаксически полной: 'Устроил бы ты хорошо: ...'. В продолжении текста, сообщающем, что именно нужно сделать, троекратно повторяется, варьируясь и обрастая новыми компонентами, одна и та же синтаксическая фигура: то бы еси..., то бы еси продлле.., продмва да бы еси Климу... Похоже, что автор несколько раз начинал фразу, но дважды забраковывал ее и приступал снова. Текст грамоты, будь он написан с первого захода, мог бы иметь вид: *Отоичи поклонь к Олоскадру. Сто бы еси добрв доспьле: сто у тьбь сиры, масло, то бы еси продале Климу. С Климомь Гиевька, Стопан с с братомь, ГАковА. Первый раз автор забыл написать масло. Дописав это слово, он начал заново: то бы еси продлле..., но вместо Климу написал с Климомь, перескочив к началу следующего предложения. С третьей попытки он наконец справился с фразой, попутно модифицировав ее: добавил вежливое $a$ А тобъ клАнаАос (<кланАюс $>$ ) и употребил форму несовершенного вида: продавал бы (с последующей, также неудачной правкой на продАва да бы). Поскольку начало следующей фразы — вторять этих слов и выписал только продолжение фразы, которое таким образом оказалось оторванным от начала. Подобным же образом оторванным от сыров оказалось масло, но автора письма это не смущало, как не смущало его и сохранение в тексте в незачеркнутом виде начатых и брошенных фрагментов. Перед своим мысленным взором автор как будто все время имел только «измененный документ» и совершенно не заботился о том, как произведенные исправления будут восприниматься читателем. 
Версию С. Г. Болотова о латинском D на фоне кириллицы, по-видимому, всерьез обсуждать не приходится, несмотря на остроумные аргументы В. Л. Янина (возможные связи с Западной Европой, а именно со славянским побережьем южной Балтики, где св. Варвара считалась покровительницей рыбаков) [Янин, Зализняк, Гиппиус 2004: 108-109]. Недавно появилась интерпретация В. К. Зиборова [2018], усматривающая во второй букве X. В его версии грамота датируется 6637 (1129) годом, то есть веком позже стратиграфической даты; такое сильное расхождение с датировкой археологического слоя и иконки, и залегавшего рядом с ней знаменитого Новгородского кодекса объясняется тем, что их в древности выбросили в глубокую яму. В версии В.К. Зиборова есть ряд привлекательных ходов (отмена столетней хронологической цезуры между датировкой грамоты и возникновением на этом месте Варваринского монастыря, впервые упоминаемого в 1138 г., или идея с альтернативным дугообразным знаком для обозначения тысяч), но многое и смущает. Трактовка: «дату на этой бересте предположительно обозначает год основания церкви св. Варвары и образовавшегося вокруг нее девичьего монастыря» - кажется подозрительно современной для XII в. (что-то вроде логотипа с фразой «since 1129»). Буква X, получающаяся у В.К. Зиборова, едва ли более убедительна, чем предлагавшиеся ранее $\phi$ и D; она имеет палеографически очень странную форму (с сомкнутыми или по крайней мере почти сомкнутыми нижними штрихами). Наконец, отметим, хотя это и не имеет прямого отношения к нашей теме, что для В.К. Зиборова вопрос о датировке иконки № 915-И преследует вспомогательную цель - передатировать сам Новгородский кодекс (которому и посвящена его статья). А последний, всё же, по языку текста псалмов (старославянскому с небольшим количеством ошибок-русизмов) и последовательно одноеровой орфографии вряд ли может относиться к концу первой трети XII в., даже если мы не будем доверять ни стратиграфии, ни действительно слишком широкому диапазону, который даёт радиоуглеродный анализ воска. Если и принимать зиборовскую транскрипцию ехм弓, то как минимум необязательно менять хронологию; X ‘600’ могло быть написано по ошибке вместо «шестой сотни» ${ }^{3}$.

Для оценки этих споров полезно отметить, что открытие точно обозначенной даты на бересте - вполне понятная мечта самых широких кругов исследователей (далеко не только «берестологов») с самого 1951 года, и это ожидание постоянно - возможно, даже бессознательно - подталкивает к подобным интерпретациям. А.В. Арциховский, встретив во фрагменте №62 сочетание слов «декабря» и «Евгения» (празднуется 24 декабря), с удовольствием отметил: «Можно надеяться на находки датированных грамот» [Арциховский 1954: 64]. Позже связь имени и названия месяца была поддержана и А. А. Зализняком [2000: 85], который, правда, в отличие от А. В. Арциховского, не видел здесь даты как таковой, а лишь некий текст «о святых, празднуемых в декабре», и усмотрел там также имя св. Феодула, от которого исследователи теперь отказались [Гиппиус, Зализняк 2015: 199-200].

\footnotetext{
3 Эту версию высказал А. А. Гиппиус при обсуждении с нами данного сюжета.
} 
Вспомним, наконец, полувековую дискуссию вокруг даты, предположительно выставленной Онфимом в грамоте № 206 (резюме см.: [Янин, Зализняк 2000: 9192]). Она до деталей напоминает наш сюжет - и несколько конкурирующих интерпретаций, и неточное соотношение со стратиграфической датой, и общий вывод о неумелой записи, наконец, даже конкретные позиции цифр, вокруг которых ведется дискуссия. Именно с онфимовской датой издатели прямо сопоставляли дату из грамоты №915-И [Янин, Зализняк, Гиппиус 2004: 109]:

«В берестяной письменности обозначение даты - вещь почти беспрецедентная. Единственный известный до сих пор пример - запись некоей даты в грамоте №206, написанной мальчиком Онфимом. Но Онфим плохо справился с этой записью, исказив две цифры из четырех (а именно, вторую и третью), так что остается даже не вполне ясно, какую именно дату он хотел изобразить <..> Характерно, что и в нашем случае писавший не очень удачно справился ровно с теми же звеньями цифровой записи. По-видимому, при обращении с цифрами оба писавших испытывали сходные затруднения: они твердо знали обозначения единиц (а тем самым и тысяч) и менее твердо - обозначения десятков и в особенности сотен (при невысоком уровне опытности такая ситуация вполне естественна)».

Благодаря открытию священника А.Н. Троицкого [Гиппиус, Зализняк 2015: 212] ныне ясно, что в грамоте Онфима даты, будь то умелой или неумелой, на са-

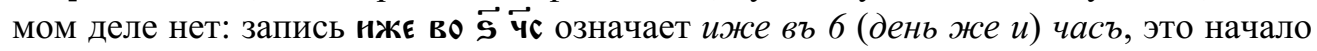
тропаря шестого часа, которое становится в один ряд с другими фрагментами церковнославянских текстов в онфимовских грамотах.

С нашей точки зрения, скорее всего, нет никакой даты и на иконке св. Варвары, которая после пересмотра анализа грамот №№ 62 и 206 остается последним берестяным документом, претендующим на наличие даты в тексте. Если представить себе, что это действительно запись из четырех знаков, то, помимо того, что половина их не имеет однозначной интерпретации, они вдобавок изображены неровно и неуверенно, с разным нажимом, имеют разный размер. Последний знак з написан с непропорционально большим отступом и приподнят (в текстуре бересты ничто таких сдвигов не диктует, в то время как и предполагаемое 2 , и предполагаемое о/л изображены прямо поверх чечевичек; последнее, собственно, неоднозначно читается именно с учётом этого обстоятельства). Подпись Варвара вокруг головы святой выполнена заметно чётче, в иной манере нанесения изогнутых штрихов и с совсем другим межбуквенным интервалом; ее вывел человек, обладающий гораздо более твёрдыми навыками письма (пусть и, судя по знаку со значением «святой (м. р.)» рядом с именами Варвары и Христа, не искушённый в греческом). В случае с «датой Онфима» хотя бы предполагалось, что мальчик неуверенно владел большими числовыми значениями букв и менял их при списывании на похожие, при этом уже освоив собственно технику письма; «дата Варвары» требует, на наш взгляд, еще более сильных допущений, а именно о наличии второго писца, еще только учившегося выводить буквы. 
Вместе с тем возможна интерпретация, согласно которой по крайней мере три фигуры из четырёх - вообще не буквы. Действительно, два неровных (почти) замкнутых элемента посередине подозрительно похожи (с поворотом на 90 градусов) на явно орнаментальные кружки на одеянии святой под воротником, состоящие из двух дуг. При таком взгляде орнаментальный характер носит и боковая линия, которую принимают за ᄅ, и вертикаль от предполагаемого $\phi / D$ (или дугообразный знак тысяч в версии В.К. Зиборова) на второй позиции. Подобные кривые могут изображать складки на одежде - ср. сложную штриховку на образе Христа с другой стороны нашей иконки или мозаику с изображением св. Варвары того же XI века из греческого монастыря Осиос-Лукас. (Собственно иконографический анализ изображения и его возможных прототипов, насколько нам известно, искусствоведами не проводился - хотя древнейшая русская икона, какими бы скромными ни были ее художественные достоинства, этого, безусловно, заслуживает.)

Такую же трактовку (как орнамент или складки одежды) в принципе допускает и последняя ломаная линия, интерпретируемая как 3, хотя, конечно, из четырех предполагаемых знаков она более всего похожа на реальную букву (ср. начерк в ранней грамоте №913). Если это буква, то имела ли она цифровое значение 7 или нет - неясно (В.К. Зиборов усматривает горизонтальную черту, играющую роль титла, но соответствующий штрих фактически касается верха предполагаемого в этой версии е и не заходит правее).

\section{2. Страж и крест: бессвязен ли набор букв из грамоты № 376}

Грамота № 376 (Неревский раскоп, усадьба И-1, условная дата 1280-1300) надо полагать, детское упражнение, аналогичное хорошо известным грамотам Онфима (но более позднее). Об этом, помимо характера схематического рисунка, говорит прежде всего то, что она представляет собой донце берестяного туеса со следами кругового шва, которое веками было классическим полем для таких упражнений. Именно на донцах написаны: онфимовская грамота № 199 (ср.: «Донышко было оторвано от туеса, вероятно, отслужившего свой срок, и дано ребенку для его занятий» [Арциховский, Борковский 1963: 17]); относящаяся к тому же времени, что и №376, грамота № 759, где точно так же, как и в №376, сверху выписан ряд цифр; грамоты №401 (конец XIV в.; «береста, которой отремонтировано дно корчаги» ${ }^{4}$; имитация письма крайне неумелой рукой) и № 865 (XII в.; полоска, вырезанная из такого донца, где «человеком, который лишь довольно приблизительно и неполно помнил алфавит и даже начертание букв освоил еще нетвердо» [Янин, Зализняк, Гиппиус 2004: 74], записан фрагмент азбуки и другие буквы; ср. похожие, уже не на донцах, несовершенные попытки изобразить азбуку: №№ 74, 444, Торж. 1). Разумеется, для уверенного заключения о возрасте

${ }^{4}$ Строго говоря, здесь несколько иной случай; при раскопках найден глиняный сосуд, дно которого было в древности отбито и заменено на берестяное. Возможно, для ремонта была взята подошедшая (и уже исписанная) деталь берестяного туеса того же диаметра. 
писавшего (а учиться писать могли и неграмотные взрослые) в каждом конкретном случае этого недостаточно, но это для логики наших рассуждений неважно; главное, что данный корпус документов относится именно к начальному освоению грамоты и его можно не смешивать с пробами пера (ср. №№ 702, 797, 966, 1085, 1089).

Грамота № 376 содержит цифры от 1 до 4, рисунок (забавная схематичная фигура человека, пересеченная крестом) и наборы букв и буквообразных знаков. Хотя ученик, безусловно, лучше владел техникой письма, чем авторы перечисленных выше грамот (кроме разве что Онфима), ряд букв интерпретируется неоднозначно; на первый взгляд их сочетания носят почти целиком бессвязный характер, поэтому выбор между альтернативными вариантами контекстом не подсказывается.

Основная надпись при рисунке находится слева от него, в четыре строки. А.В. Арциховский [1963: 76] отметил как осмысленную только финальную последовательность стражь и оговорил, что вообще описывает документ только для полноты картины: «Настоящая находка включена в общую нумерацию грамот, поскольку туда надо включать всякую исписанную бересту...». В дальнейшем новых интерпретаций в печати не предлагалось. Попробуем это сделать, двигаясь от отрезка стражь назад 5 .

Слово стражь — церковнославянское с неполногласием. Перспективно попытаться увидеть в записи из грамоты № 376 видоизмененный церковный текст, аналогично грамотам Онфима с их цитатами из Псалтири и Часослова (см. выше, раздел 2.1). В предшествующих буквах Акช тоже можно увидеть церковнославянское слово, а именно Ако. Запись ४ вместо о можно объяснить как опиской (смешением под пером ученика похожих букв), так и фонетически: исследованиями последнего времени уже накоплен целый ряд свидетельств уканья в безударной позиции в берестяных грамотах (лоуни в № 88, исправленное на лони; умули в № 395 вместо умоли, жалуби в № 301 вместо жалоби [Гиппиус, Зализняк 2015: 205, 236]6).

Поиск в церковных текстах сочетания гако стражь в готовом виде находит ряд сходных пассажей в составе служб святым, традиционно уподобляемых в гимнографии стражам (фрочроí), например, в Ильиной книге XI в. (здесь иная падеж-

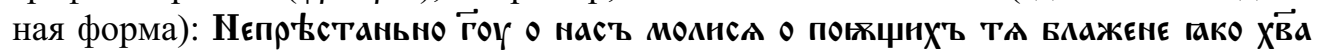

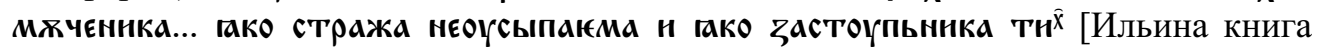
2005: 294].

${ }^{5}$ При обсуждении статьи А.А. Гиппиус указал нам на ранее обдумывавшуюся им теоретическую возможность чтения надписи на рисунке по строкам снизу вверх (с иной интерпретаци-

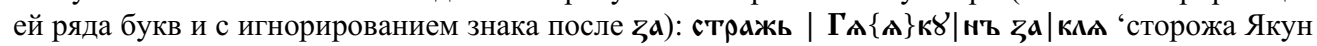
заклял’ (с такой же записью начального йота в имени через г, как в грамотах №528 и Вол. 1, см. раздел 1.2 настоящей статьи). О возможности чтения $\rho$ вместо г см. примечание 8 . Есть также чтение С. М. Михеева, также ориентированное снизу вверх и по составу букв совпадающее с пре-

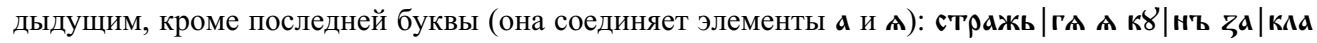
'постаравшись, я денег (или: Якун (?)) заложил (?) [в этот туес (?)]'.

${ }^{6}$ Сюда же и гоз४ в №330 вместо гузу [Зализняк 2000: 99], хотя и с оговорками (замена гласного тут носит лексический характер по образцу И. ед. гуза́, в В. ед. было гу́зу). 
Конкурентоспособно также похожее сочетание ґко стражь(ии) с русским рефлексом и элементом бытовой орфографии: $e \rightarrow b$ (возможно, под влиянием существительного стражь), для которого находится неплохая параллель в Постной Триоди - тропарь крестобогородичен из службы на среду ваий (шестой недели поста). Современный текст здесь такой: Видящии висима Хрсте, чистш рождиал ТА, повьсившаго на водахъ землю Чльвколюбче, взываше: оувы Мнь, что странное видъніе, какш зайде доброта Твон, сладчайшій Сйе, безмьрнан, величаю Твою млсть, ıкш cтраждеши волею за вcbxъ. К сожалению, мы пока не можем указать параллелей для этого текста в древнерусской письменности (в частности, другой вариант крестобогородична с тем же инципитом из рукописи РНБ, Соф. 96 - нотированный стихирарь XIII в. новгородского происхождения - обсуждаемого текста не содержит 7 ).

Если принять последний вариант, то появляется возможность истолковать и еще

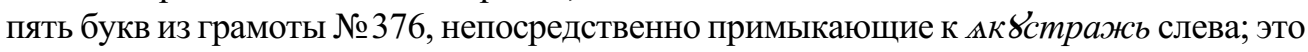

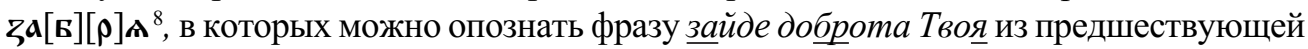
части того же тропаря. Из первого слова взяты две первых буквы, из второго - две следующие (на тех же позициях); из последнего - последняя буква. Это напоминает сцепление фрагментов слов, в том числе гаплографическое, которое практиковал Онфим (только наш ученик уделяет меныше внимания сегментации на слоги).

Наконец, перед $\mathbf{3} \mathbf{a}[\mathbf{6}][\boldsymbol{\rho}] \mathbf{\mathbf { \mathbf { A } }}$ читается и открывает всю обсуждаемую последовательность букв отрезок (-)камкъ (второе А переправлено из а), с весьма странной фигурой в начале, внешне больше всего похожей на перевернутый зеркальный ъ, возможно, слитый с последующим к. Отметим, что на листе в разных местах есть другие буквы, написанные верхом вниз по отношению к рисунку, цифрам и основной надписи, поэтому, возможно, этот знак и не имеет отношения к нашему тексту. Начальный отрезок можно прочесть как целое слово $(o) \kappa<a>A н b$ (автор сначала написал $(o) \kappa \wedge a н ъ$, переставив две похожие буквы, но потом исправил только вторую). Тогда в первой фигуре, если это действительно принадлежащий дальнейшему тексту геометрически преобразованный ъ, можно - предельно осторожно - предположить знак для $o$, записанный с нарушением обычного для бытовой орфографии запрета на еры в начале слога, из которого на бересте известно только три исключения: №№561, 737 и 927 [Зализняк 2004: 24], ср. также предположительно читаемое погребъше в в надписи на Городище о смерти Всеволода Мстиславича в 1138 г. [Гиппиус, Михеев 2019: 38]; незнание этой тонкой конвенции вполне естественно для ученика. Впрочем, для реконструкции это не принципиально, поскольку писец заведомо мог записывать не целые слова, а их фрагменты.

7 Благодарим Т.И. Афанасьеву и Р.Н. Кривко за консультацию.

${ }^{8}$ Буква $\rho$ (интерпретированная так в издании) допускает также чтение г (с большой засечкой, наклоненной внутрь); именно так ее читают А.А. Гиппиус и С. М. Михеев (см. выше, примечание 5). Действительно, в стражь р имеет иную форму, с замкнутой петлей, но в составе цифр над рисунком иначе выглядит и $\mathbf{r}$, с вертикальной засечкой; перед нами некоторая промежуточная конфигурация. У буквы в на фотографии не видно нижней горизонтали, но иное истолкование (например, небрежно написанное к) менее вероятно (в чтениях А. А. Гиппиуса и С. М. Михеева она игнорируется как незначимая или как часть рисунка). 
Слово оканнъ (-ныл) весьма частотно в богослужебных текстах и присутствует, в частности, в песнопениях недели ваий из Постной Триоди, предшествующих среде, ср. современный текст: Помышлдю множество согрбшеній, и оуюзвленъ жаломъ совъсти, ґкоже въ пламени болю окаґнный (вторник недели ваий; еще два примера в понедельник).

Неумелое изображение фигуры человека, пересеченной огромным крестом, в сочетании с фрагментами богослужебных текстов (тем более если среди них крестобогородичный тропарь) наводит на мысль о попытке срисовать икону (ср. упомянутую выше грамоту №915-И, а также, особенно, отпечаток двух фигур святых и большого креста на грамоте №955), хотя, конечно, никакой обязательности в этом нет (ср. вполне светских онфимовских человечков рядом с фрагментом тропаря в грамоте № 206). Ученик, как и Онфим, явно не придавал никакого связного смысла своим тренировочным выпискам, тем более в комплексе с рисунками (если верна наша реконструкция, сочетание вышло кощунственным).

Еще раз подчеркнем сугубую гипотетичность такого анализа, который, возможно, смогут уточнить дальнейшие находки в гимнографическом корпусе. В любом случае, идентификация грамоты № 376 как детского упражнения в письме представляется вполне надёжной, а связь финального отрезка Ак४стражь с богослужебны-

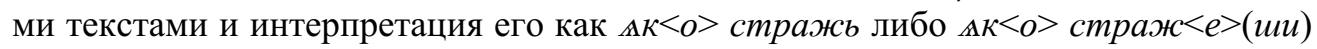
кажется высоковероятной.

\section{Литература}

Арияиховский A.В. Новгородские грамоты на бересте (из раскопок 1952 г.). М., 1954.

Арцуиховский А. В. Новгородские грамоты на бересте (из раскопок 1958-1961 гг.). M., 1963.

Аризиховский А. В., Борковский В. И. Новгородские грамоты на бересте (из раскопок 1956-1957 гг.). М., 1963.

Васильев В. Л. Славянские топонимические древности Новгородской земли. М., 2012.

Гиппиус A.A. О нескольких персонажах новгородских берестяных грамот XII века // Янин В. Л., Зализняк А. А., Гиппиус А. А. Новгородские грамоты на бересте (из раскопок 1997-2000 гг.). М., 2004a. С. 164-182.

Гиппиус A.A. К прагматике и коммуникативной организации берестяных грамот // В. Л. Янин, А. А. Зализняк, А. А. Гиппиус. Новгородские грамоты на бересте (из раскопок 1997-2000 гг.). М., 2004б. С. 183-232.

Гиппиус А. А. К изучению княжеских уставов Великого Новгорода: «Устав князя Ярослава о мостех» // Славяноведение. 2005. № 4. С. 9-24.

Гиппиус A. A. Скандинавский след в истории новгородского боярства (в развитие гипотезы А.А. Молчанова о происхождении посадничьего рода ГюрятиничейРоговичей) // The Slavicization of the Russian North. Mechanisms and Chronology. Ed. by Juhani Nuorluoto. (Slavica Helsingiensia 27.) Helsinki, 2006. P. 93-108. 
Гиппиус А.А., Зализняк А. А. Поправки и замечания к чтению ранее опубликованных берестяных грамот // Янин В.Л., Зализняк А. А, Гиппиус А. А. Новгородские грамоты на бересте (из раскопок 2001-2014 гг.). Том XII. М., 2015. С. 196-275.

Гиппиус А. А., Михеев С. М. Надписи-граффити церкви Благовещения на Городище: предварительный обзор // Архитектурная археология. 2019. № 1. С. 35-54.

Зализняк $A$. A. Поправки и замечания к чтению ранее опубликованных берестяных грамот // Янин В. Л., Зализняк А. А. Новгородские грамоты на бересте (из раскопок 1990-1996 гг.). Палеография берестяных грамот и их внестратиграфическое датирование. М., 2000. С. 82-122.

Зализняк А. А. Древненовгородский диалект. 2-е изд. М., 2004.

Зализняк А.А. «Эффект Лукерьи»: переход ол > $о$ в истории русского языка // А.Ф. Журавлев, Ф.Б. Успенский (ред.). Славянское и балканское языкознание: Славистика. Индоевропеистика. Культурология. К 90-летию со дня рождения Владимира Николаевича Топорова М., 2019. С. 82-96.

Зиборов В.К. О древнейшей книге Руси // Вестник Санкт-Петербургского университета. История. Т. 63. 2018. Вып. 3. С. 949-956.

Ильина книга. Рукопись РГАДА, Тип. 131. / Лингвистическое издание, подготовка греческого текста, комментарии, словоуказатели В. Б. Крысько. М., 2005.

Крыссько В.Б. Новые материалы к истории древненовгородского номинатива на -е // Вопросы языкознания. 1993. № 6. С. 78-88.

Кукушкин И. П., Гиппиус А.А., Зализняк А.А. Первая берестяная грамота из Вологды // Российская археология. 2018. № 1, С. 164-172.

Кулешов Вяч. С. Колбяги и Ладожское ярлство (заметки к теме) // Северная Русь и Балтика в середине ХІІ столетия. СПб., 2014. С. 129-139.

Кулешов Вяч. С., Мачинский Д. А. Колбяги // Ладога и Глеб Лебедев: восьмые чтения памяти Анны Мачинской. СПб., 2004, С. 207-227.

Мачинский Д. А., Мачинская А. Д. Северная Русь, Русский Север и Старая Ладога в VIII-ХI вв. // Культура Русского Севера. Л., 1988. С. 52-54.

Михайлова E.P. Северные окраины Древней Руси: история поиска колбягов // Северо-Запад: этноконфессиональная история и историко-культурный ландшафт-2. Восьмые Шёгреновские чтения. СПб., 2019. С. 7-15.

Пенькова Я.А. От ретроспективности к проспективности: грамматикализация предбудущего в языках Европы // Вопросы языкознания, 2018. №2. С. 53-70.

Пенькова Я.А. Предбудущее (второе будущее) в древненовгородском диалекте: время или наклонение? // Russian linguistics. Vol. 43. 2019. № 1. С. 65-77.

Рыцзевская E. A. К варяжскому вопросу // Известия АН CCCP. VII сер. Отделение общественных наук. 1934. № 7. С. 485-532.

Янин В. Л., Зализняк А. А. Новгородские грамоты на бересте (из раскопок 1990 1996 гг.). Палеография берестяных грамот и их внестратиграфическое датирование. М., 2000.

Янин В.Л., Зализняк А. А, Гиппиус А. А. Новгородские грамоты на бересте (из раскопок 1997-2000 гг.). М., 2004. 


\section{Dmitry V. Sitchinava \\ Vinogradov Russian Language Institute of the Russian Academy of Sciences / Higher School of Economics - National Research University \\ (Moscow, Russia) \\ mitrius@gmail.com}

\section{ON THE INTERPRETATION OF CERTAIN BIRCHBARK LETTERS}

The article proposes amendments and additions to the interpretation of four birchbark documents. The mysterious word kob'azhanin in letter No. 831 is interpreted as a derivative of the ethnonymic base kblb'ag- (it thus contributes to the body of evidence on the ethnic category of Kolbyags). In letter No. 528, the segments gievk'a, g'akov'a, which had previously been regarded as the Cyrillic numeral ' 3 ' ( $(\vec{\Gamma})$ preceding the names Ievko and Yakov, were reinterpreted as renderings of an initial [j] in these two names using the letter $g$. The key evidence for these readings comes from the birchbark letters discovered in recent years (Novgorod No. 1102 and Vologda No. 1, respectively), where the relevant phonetic effects have been discerned. We consider these two readings to be quite reliable. In addition to these readings, we also offer versions for the analysis of documents No. 915-I and 376, which feature drawings. Even the presence of a meaningful text is here a matter of conjecture, so we cannot insist on these versions with certainty. Document No. 915-I (the oldest Russian icon) does not seem to contain a date, and document No. 376 probably features fragments of a church text recorded by the pupil who engraved both the letters and the drawing on the birchbark.

Keywords: birchbark letters, Old Novgorod dialect, phonetic change, orthography, Kolbyags, drawings, hymnography.

\section{References}

Artsikhovskiy A. V. Novgorodskie gramoty na bereste (iz raskopok 1952 g.). Moscow, 1954.

Artsikhovskiy A. V. Novgorodskie gramoty na bereste (iz raskopok 1958-1961 gg.). Moscow, 1963.

Artsikhovskiy A. V., Borkovskiy V.I. Novgorodskie gramoty na bereste (iz raskopok 1956-1957 gg.). Moscow, 1963.

Gippius A. A. O neskol'kikh personazhakh novgorodskikh berestyanykh gramot XII veka. In: Yanin V.L., Zaliznyak A.A., Gippius A. A. Novgorodskie gramoty na bereste (iz raskopok 1997-2000 gg.). Moscow, 2004a. S. 164-182.

Gippius A.A. K pragmatike i kommunikativnoy organizatsii berestyanykh gramot. In: V.L. Yanin, A. A. Zaliznyak, A. A. Gippius. Novgorodskie gramoty na bereste (iz raskopok 1997-2000 gg.). Moscow, 2004b. S. 183-232.

Gippius A.A. K izucheniyu knyazheskikh ustavov Velikogo Novgoroda: «Ustav knyazya Yaroslava o mostekh». Slavyanovedenie. 2005. №4. S. 9-24. 
Gippius A. A. Skandinavskiy sled $v$ istorii novgorodskogo boyarstva (v razvitie gipotezy A. A. Molchanova o proiskhozhdenii posadnich'yego roda Gyuryatinichey-Rogovichey). The Slavicization of the Russian North. Mechanisms and Chronology. Ed. by Ju. Nuorluoto (=Slavica Helsingiensia 27.) Helsinki, 2006. P. 93-108.

Gippius A.A., Mikheev S.M. Nadpisi-graffiti tserkvi Blagoveshcheniya na Gorodishche: predvaritel'nyy obzor. Arkhitekturnaya arkheologiya. 2019. № 1. S. 35-54.

Gippius A. A., Zaliznyak A. A. Popravki i zamechaniya k chteniyu ranee opublikovannykh berestyanykh gramot. In: Yanin V. L., Zaliznyak A. A, Gippius A. A. Novgorodskie gramoty na bereste (iz raskopok 2001-2014 gg.). Tom XII. Moscow, 2015. S. 196-275.

Il'ina kniga. Rukopis' RGADA, Tip. 131. Lingvisticheskoe izdanie, podgotovka grecheskogo teksta, kommentarii, slovoukazateli V. B. Krys'ko. Moscow, 2005.

Krys'ko V.B. Novye materialy k istorii drevnenovgorodskogo nominativa na -e. Voprosy yazykoznaniya, 1993. №6. S. 78-88.

Kukushkin I.P., Gippius A.A., Zaliznyak A.A. Pervaya berestyanaya gramota iz Vologdy. Rossiyskaya arkheologiya, 2018. № 1. S. 164-172.

Kuleshov Vyach. S. Kolbyagi i Ladozhskoe yarlstvo (zametki k teme). Severnaya Rus' i Baltika v seredine XII stoletiya. St. Petersburg, 2014. S. 129-139.

Kuleshov Vyach. S., Machinskiy D. A. Kolbyagi. Ladoga i Gleb Lebedev: vos'mye chteniya pamyati Anny Machinskoy. St. Petersburg, 2004. S. 207-227.

Machinskiy D. A, Machinskaya A. D. Severnaya Rus', Russkiy Sever i Staraya Ladoga v VIII-XI vv. Kul'tura Russkogo Severa. Leningrad, 1988. S. 52-54.

Mikhaylova E. R. Severnye okrainy Drevney Rusi: istoriya poiska kolbyagov. Severo-Zapad: etnokonfessional'naya istoriya $i$ istoriko-kul'turnyy landshaft-2. Vos'mye Shegrenovskie chteniya. St. Petersburg, 2019. S. 7-15.

Pen'kova Ya. A. Ot retrospektivnosti k prospektivnosti: grammatikalizatsiya predbudushchego v yazykakh Evropy. Voprosy yazykoznaniya. 2018. №2. S. 53-70.

Pen'kova Ya. A. Predbudushchee (vtoroe budushchee) v drevnenovgorodskom dialekte: vremya ili naklonenie? Russian linguistics. Vol. 43. 2019. № 1. S. 65-77.

Rydzevskaya E. A. K varyazhskomu voprosu. Izvestiya Akademii nauk SSSR. VII ser. Otdelenie obshchestvennykh nauk. 1934. №7. S. 485-532.

Vasil'yev V.L. Slavyanskie toponimicheskie drevnosti Novgorodskoy zemli. Moscow, 2012.

Yanin V.L., Zaliznyak A. A, Gippius A. A. Novgorodskie gramoty na bereste (iz raskopok 1997-2000 gg.). Moscow, 2004.

Yanin V.L., Zaliznyak A. A. Novgorodskie gramoty na bereste (iz raskopok 19901996 gg.). Paleografiya berestyanykh gramot $i$ ikh vnestratigraficheskoe datirovanie. Moscow, 2000.

Zaliznyak A. A. «Effekt Luker'i»: perekhod ol > o v istorii russkogo yazyka. Slavyanskoe i balkanskoe yazykoznanie: Slavistika. Indoevropeistika. Kul'turologiya. K 90-letiyu so dnya rozhdeniya Vladimira Nikolaevicha Toporova. A. F. Zhuravlev, F. B. Uspenskiy (red.). Moscow, 2019. S. 82-96.

Zaliznyak A. A. Drevnenovgorodskiy dialekt. 2-e izd. Moscow, 2004. 
Zaliznyak A. A. Popravki i zamechaniya k chteniyu ranee opublikovannykh berestyanykh gramot. In: Yanin V.L., Zaliznyak A. A. Novgorodskie gramoty na bereste (iz raskopok 1990-1996 gg.). Paleografiya berestyanykh gramot i ikh vnestratigraficheskoe datirovanie. Moscow, 2000. S. 82-122.

Ziborov V.K. O drevneyshey knige Rusi. Vestnik Sankt-Peterburgskogo universiteta. Istoriya. T. 63, 2018. Vyp. 3. S. 949-956. 